\title{
SYNTHESIS OF IMINOPHOSPHORANES AS LIGANDS FOR ORGANOMETALLIC COMPOUNDS
}

\author{
Adolfo Fernández-Figueiras * Fátima Lucio-Martínez, Paula Munín, Francisco Reigosa , \\ José M. Vila, M. Teresa Pereira, Paula Polo-Ces \\ Departamento de Química Inorgánica, Facultad de Química, Campus Vida, \\ Universidade de Santiago de Compostela, adolfo.fernndez@rai.usc.es
}

\begin{abstract}
Iminophosphoranes are organic compounds of general composition $\mathrm{R}_{3} \mathrm{P}=\mathrm{NR}$ and can be considered as nitrogen analogues to phophorus ylides. They can be obtained by the Staudinger [1] and Kirsanov [2] reactions. This compounds have multiple applications: they can be used as intermediates in reactions such as the Aza-Wittig [3], as a protecting group for amines or as a ligands for coordinated or cyclometallated compounds [4].

The $\mathrm{P}=\mathrm{N}$ bond is highly polarized, so that the nitrogen bears a partial negative charge. This feature makes them act as $\sigma$-donors with only minor $\pi$-acceptor properties, so when forming coordination compounds they can be displaced by other ligands [5].
\end{abstract}

\section{Keywords}

Iminophosphorane, cyclometallated, organometallic

\section{Introduction}

The chemistry of iminophosphoranes has had a steady growth and it has been the focus of considerable interest in the last decade. The biological applications and anticancer properties of coordinated and cyclometallated iminophosphoranes of $\mathrm{Pd}(\mathrm{II}), \mathrm{Pt}(\mathrm{II})$ and $\mathrm{Au}$ (III) have been studied due to the non- toxic character of iminophosphoranes can be synthesized [6]. An extra advantage is that the $\mathrm{P}$ atom in the $\mathrm{PR}_{3}$ fragment can be used as a "spectroscopic marker" to study the in vitro stability (and oxidation state) by ${ }^{31} \mathrm{P}\left\{{ }^{1} \mathrm{H}\right\} N M R$ [7]. Moreover, the luminescent properties of some of these compounds make them in molecular probes in teragnosis potentially useful [8]. On the other hand, iminophosphorane cyclometallated compounds are active in many types of catalysis such as Suzuki or Heck cross-coupling reactions [9].

Consequently, our research group has considered important to study the synthesis of new palladium (II) cyclometallated iminophosphorane compounds and their reactivity with phosphine ligands. 


\section{Results and discussion}

2-(methylthio)aniline iminophosphoranes derivatives can act as tridentante ligands. Such ligands may be easily obtained by the Staudinger reaction as depicted in Scheme 1<smiles>CSc1ccccc1N</smiles><smiles>Cc1ccc(P(c2ccc(C)cc2)c2ccc(C)cc2)cc1</smiles>

eter t.a.

$2 \mathrm{~h}$<smiles>CSc1ccccc1N=P(c1ccc(C)cc1)(c1ccc(C)cc1)c1ccc(C)cc1</smiles>

1

Scheme 1

Compound $\mathbf{2}$ may be obtained by the reaction of a palladium salt with the iminophosphorane ligand. The presence of a base is not necessary but facilitates the cyclometallation reaction and prevents de formation of the $[\mathrm{N}, \mathrm{S}]$ coordination compound.<smiles>CSc1ccccc1N=P(c1ccc(C)cc1)(c1ccc(C)cc1)c1ccc(C)cc1</smiles>

1

$$
\mathrm{Na}_{2} \mathrm{PdCl}_{4} \quad \mathrm{NaOAc} \quad \frac{\mathrm{MeOH} 80^{\circ} \mathrm{C}}{18 \mathrm{~h}}
$$

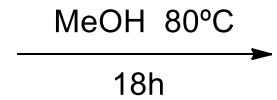

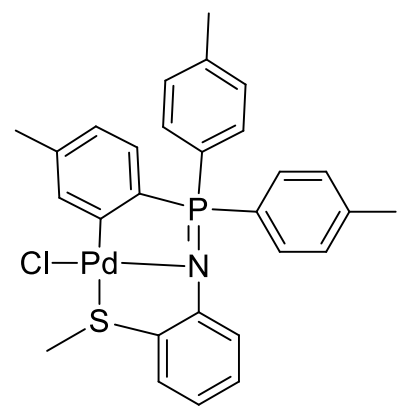

2

Scheme 2

Compound 2 obtained in this reaction is an air-stable bright yellow solid. The metal atom shows a square-planar geometry and has two covalent coordinate bonds with the nitrogen and the sulfur atoms and one $\sigma$ bond with de carbon atom.

Compound 3 bearing a triphenylphosphine ligand can be made by the direct reaction of 2 with the phosphine and ammonium hexafluorophosphate.<smiles></smiles>

2

$$
\mathrm{PPh}_{3}
$$

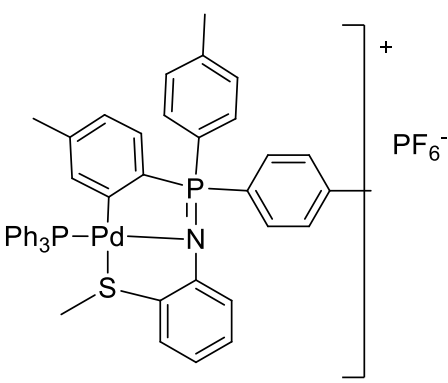

3 
The ${ }^{1} \mathrm{H}$ NMR analysis for 2 confirms the formation of the compound (Figure 2). The ${ }^{1} \mathrm{H}$ NMR spectrum shows absence of the $\mathrm{C}(2)-\mathrm{H}$ proton.

jv1 ${ }_{\text {juffd } 136.400}$
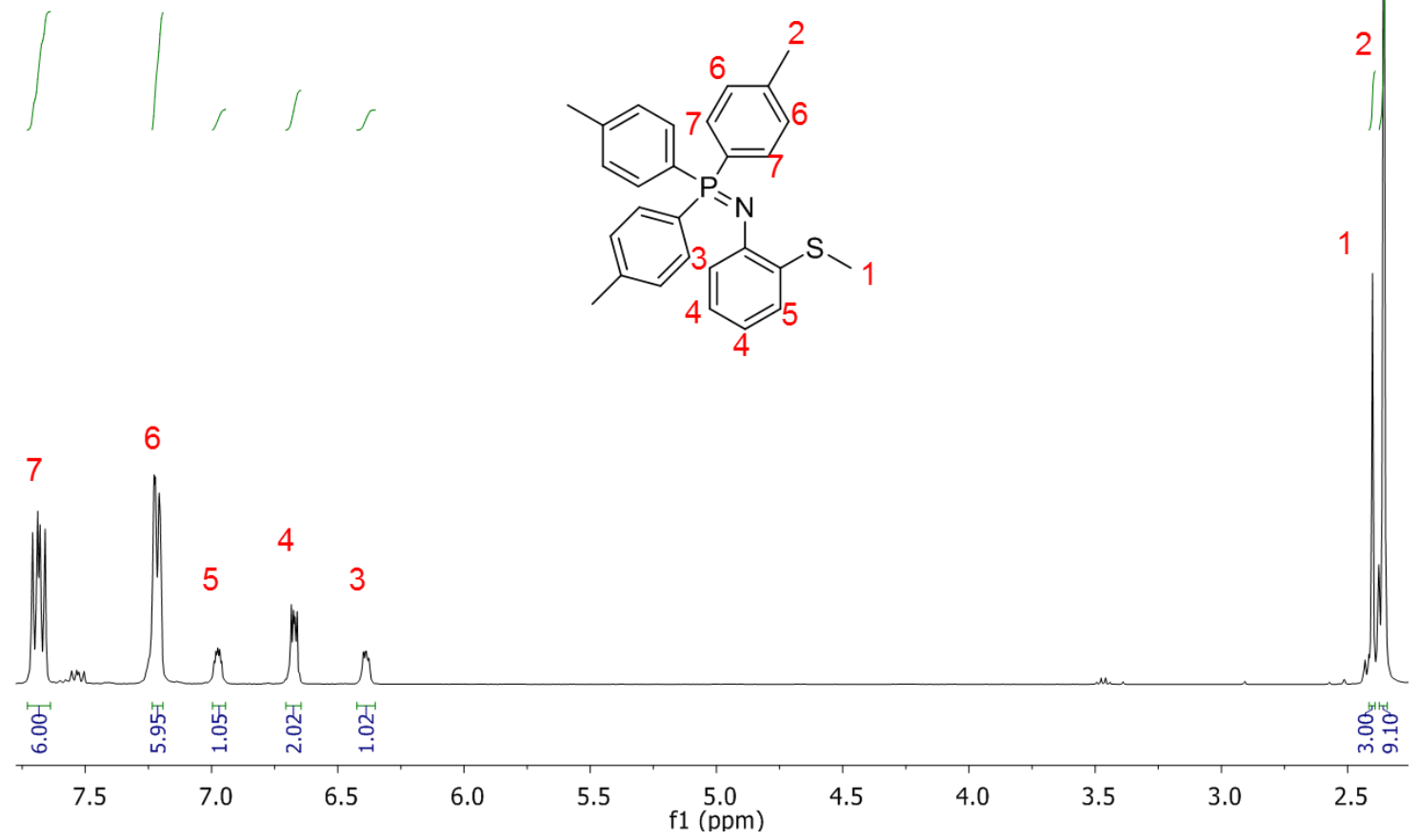

Figure 1: ${ }^{1} \mathrm{H}$ NMR spectrum for 1

$\underset{\text { jv1affd } 140.400}{1 \mathrm{H}}$
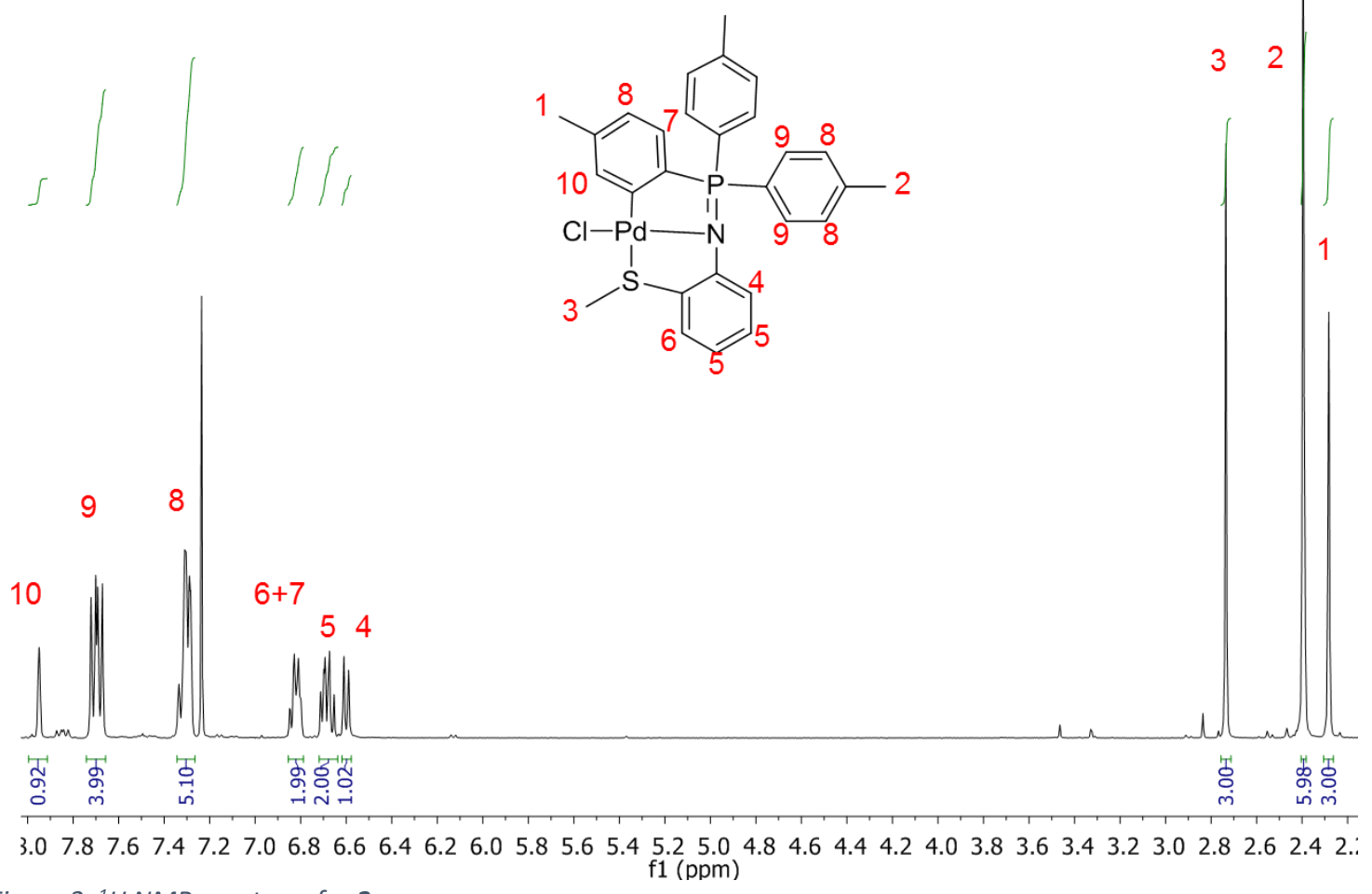

Figure 2: ${ }^{1} \mathrm{H}$ NMR spectrum for 2 

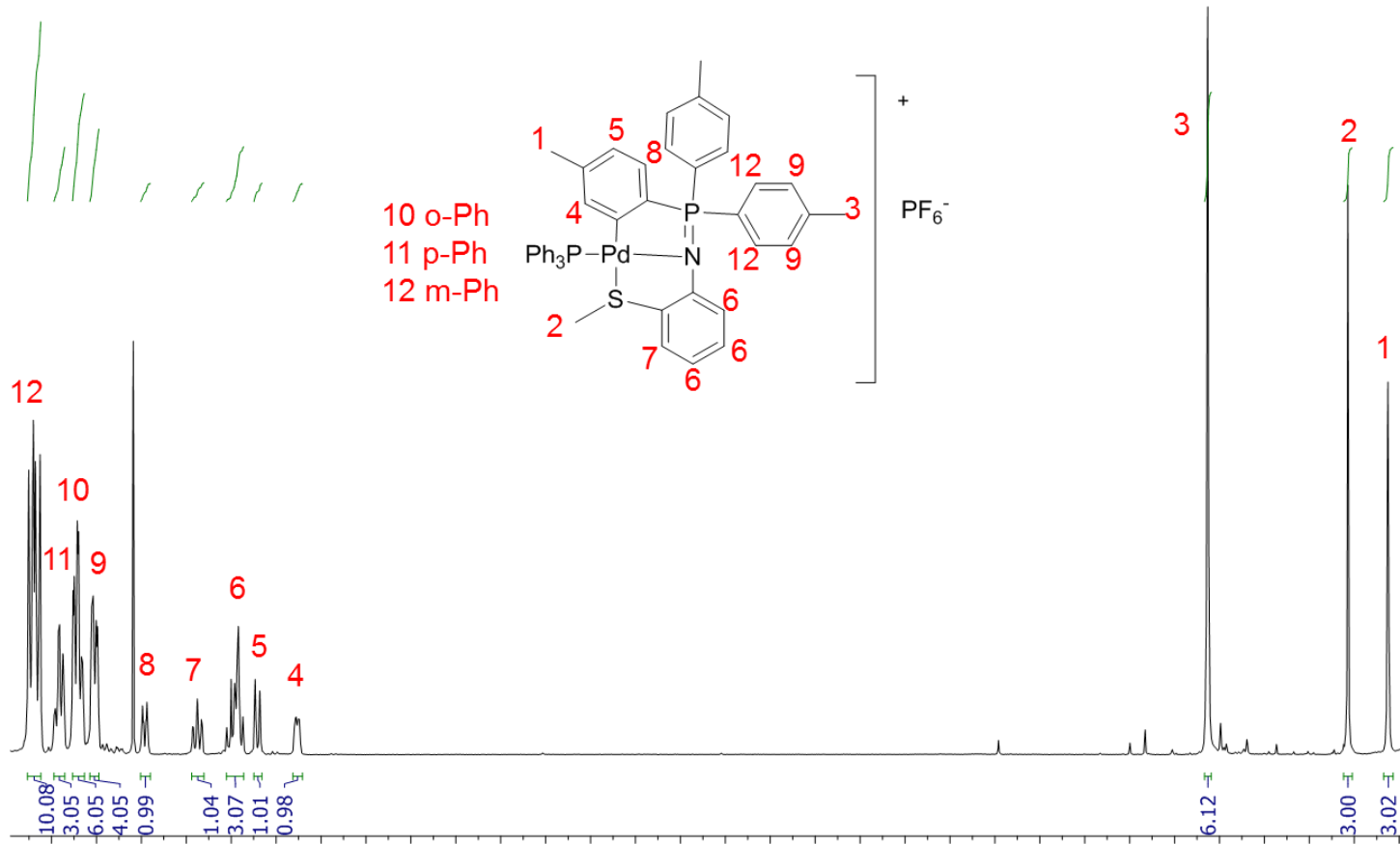

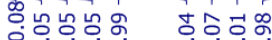

$7.67 .47 .27 .06 .86 .66 .46 .26 .05 .85 .65 .45 .25 .0 \quad 4.8 \quad 4.64 .44 .24 .03 .83 .63 .43 .23 .02 .82 .62 .42 .22 .01 .81$ Figure 3: ${ }^{1} \mathrm{H}$ NMR spectrum for 3
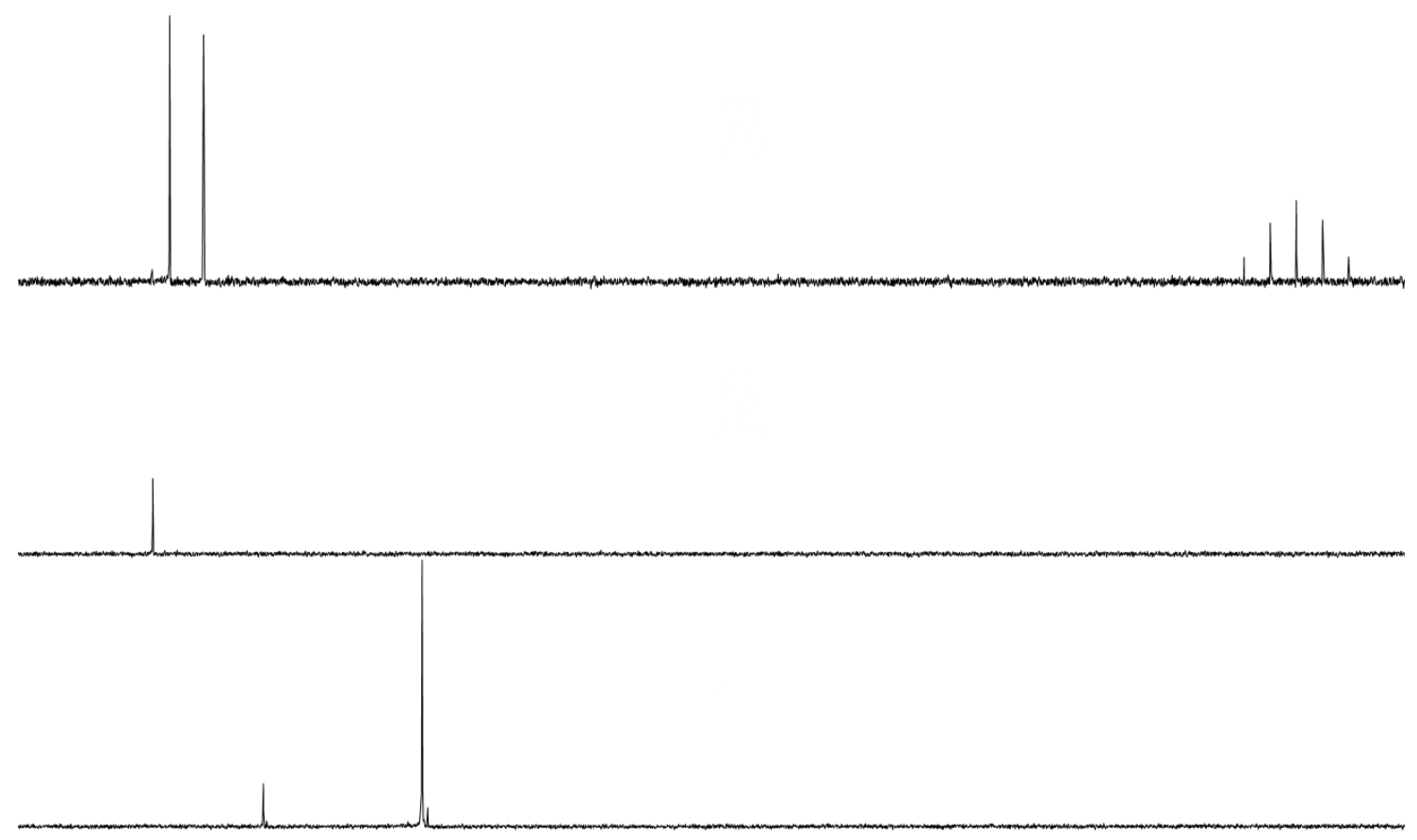

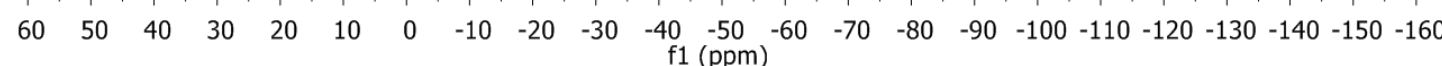
Figure 4. ${ }^{31} \mathrm{P}\{1 \mathrm{H}\}$ NMR spectrum for $\mathbf{3}$ (top), 2 (middle), 1 (bottom)

Crystals of compound $\mathbf{2}$ where obtained by slow evaporation from a chloroform solution. The X-ray diffraction study of the crystal confirms the formation of the cyclometallated compound. 


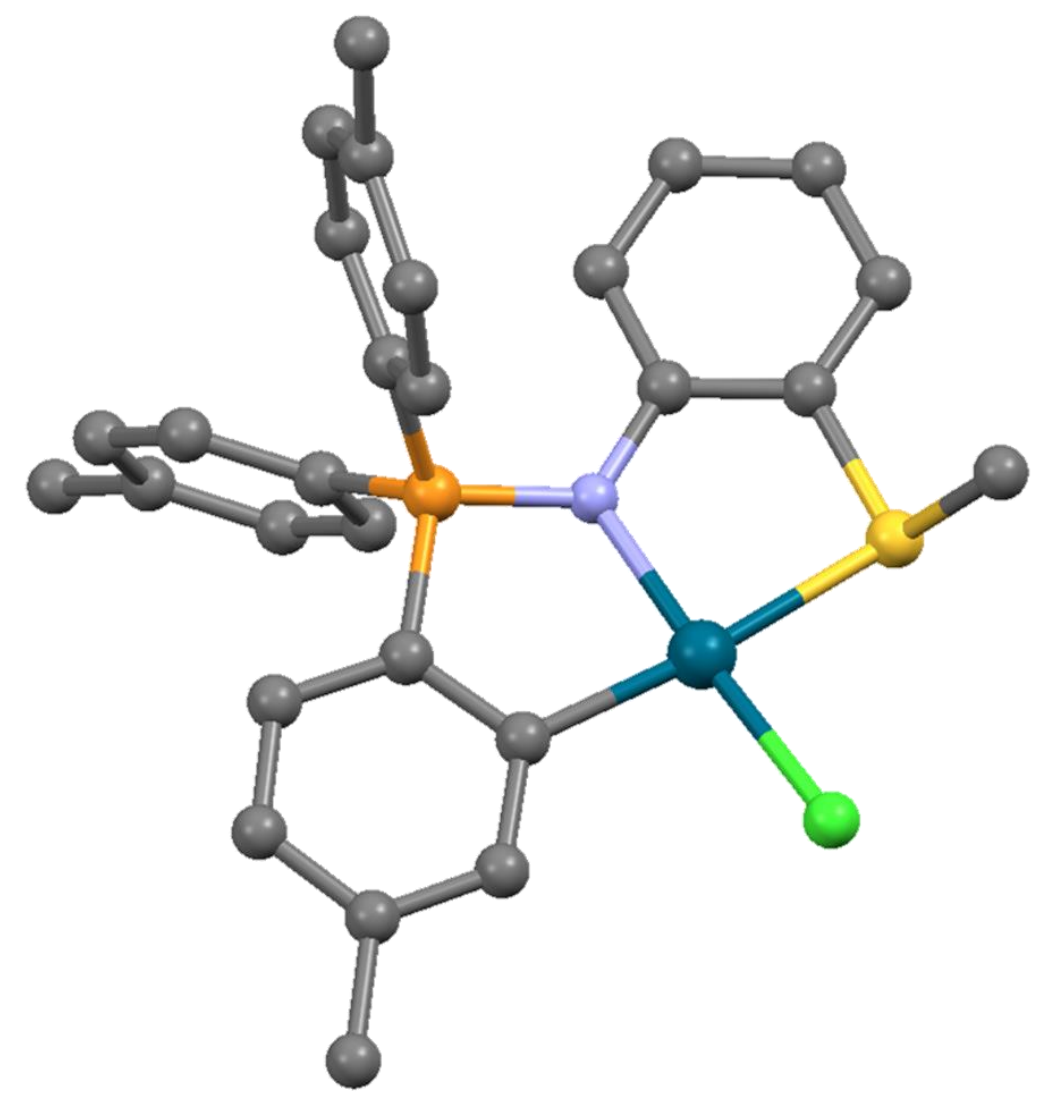

\begin{tabular}{|c|c|}
\hline Empirical Formula & $\mathrm{C}_{28} \mathrm{H}_{27} \mathrm{ClNPPdS}$ \\
\hline Formula Weight & 528.39 \\
\hline Temperature & $100.0(1) \mathrm{K}$ \\
\hline Wavelength & $0.71073 \AA$ \\
\hline Crystal system & Orthorhombic \\
\hline Space group & $\mathrm{P} 2(1) 2(1) 2(1)$ \\
\hline Unit cell dimensions & $\begin{array}{l}a=10.862(5) \AA \quad \alpha=90.000(5)^{\circ} \\
b=12.097(5) \AA \quad \beta=90.000(5)^{\circ} \\
c=19.282(5) \AA \quad \gamma=90.000(5)^{\circ}\end{array}$ \\
\hline Volume & $2533.6(17) \AA^{3}$ \\
\hline $\mathbf{Z}$ & 4 \\
\hline Density (calculated) & $1.527 \mathrm{Mg} / \mathrm{m}^{3}$ \\
\hline Absorption Coefficient & $1.001 \mathrm{~mm}^{-1}$ \\
\hline Crystal size & $0.44 \times 0.17 \times 0.06 \mathrm{~mm}$ \\
\hline$\theta$ Range for data collection & $1.99-28.28^{\circ}$ \\
\hline Index ranges & $-14<=\mathrm{h}<=14,-15<=\mathrm{k}<=15,-25<=\mathrm{l}<=25$ \\
\hline Reflections collected & 23880 \\
\hline Independent reflections & $6273\left[\mathrm{R}_{\text {int }}=0.0485\right]$ \\
\hline Data/restriction/parameters & $6273 / 0 / 298$ \\
\hline Goodness-of-fit on $F^{2}$ & 0.879 \\
\hline Final R Indices [I>2 $\sigma(I)]$ & $R_{1}=0.0380, w R_{2}=0.0876$ \\
\hline $\mathbf{R}$ indices (all data) & $R_{1}=0.0435, w R_{2}=0.0913$ \\
\hline
\end{tabular}




\section{Experimental}

$\left[\mathrm{Na}_{2} \mathrm{PdCl}_{4}\right], \mathrm{PPh}_{3}$ and 2-(methylthio)aniline were obtained from Aldrich and were used without further purification.

\section{Synthesis of 2-(methylthio)phenylazide}

To a mixture of 2-(methylthio)aniline $(1000 \mathrm{mg}, 7.183 \mathrm{mmol})$, in water $\left(1.5 \mathrm{~cm}^{3}\right)$, ethyl acetate $\left(7 \mathrm{~cm}^{3}\right)$ and $\mathrm{HCl} 37 \%\left(1.5 \mathrm{~cm}^{3}\right)$ was added dropwise sodium nitrite $(843 \mathrm{mg}$, $12.211 \mathrm{mmol}$ ) in water under vigorous stirring at $0-5^{\circ} \mathrm{C}$. After $30 \mathrm{~min}$ aqueous $\mathrm{NaN}_{3}(793$ $\mathrm{mg}, 12.211 \mathrm{mmol}$ ) was added dropwise to the reaction mixture at $0-5^{\circ} \mathrm{C}$ for 30 minutes. The mixture was extracted with ethyl acetate and washed with water. The organic layer was evaporated and a pale yellow powder was obtained. Yield $1021 \mathrm{mg}$ (86\%).

\section{Synthesis of the compound 1}

To a solution of 2-(methylthio)phenylazide $(163 \mathrm{mg}, 0,986 \mathrm{mmol})$ in diethyl ether $(20$ $\left.\mathrm{cm}^{3}\right)$ was added tri( $p$-tolyl)phosphine $(300 \mathrm{mg}, 0,986 \mathrm{mmol})$ and stirred at room temperature for two hours. The solvent of the resulting solution was evaporated to dryness giving a yellow powder. Yield $398 \mathrm{mg}$ (91.5\%).Anal. Calc. for $\mathrm{C}_{28} \mathrm{H}_{28} \mathrm{NPS}$ : C, 76.16; $\mathrm{H}, 6.39 ; \mathrm{N}, 3.17$. Found: $\mathrm{C}, 76.18 ; \mathrm{H}, 6.42 ; \mathrm{N}, 3.17 .{ }^{1} \mathrm{H}$ NMR $(\mathrm{CDCl} 3): \sigma=2.36(\mathrm{~s}, 9 \mathrm{H}), 2.40$ $(\mathrm{s}, 3 \mathrm{H}), 6.39(\mathrm{~m}, 1 \mathrm{H}), 6.67(\mathrm{~m}, 2 \mathrm{H}), 6.97(\mathrm{~m}, 1 \mathrm{H}) 7.21(\mathrm{~m}, 6 \mathrm{H}), 7.68(\mathrm{~m}, 6 \mathrm{H}){ }^{31} \mathrm{P}\left\{{ }^{1} \mathrm{H}\right\} \mathrm{NMR}$ $(\mathrm{CDCl} 3): \sigma=0.06 \mathrm{~s}$.

\section{Synthesis of the compound 2}

To a mixture of $\left[\mathrm{Na}_{2} \mathrm{PdCl}_{4}\right]$ (75 mg, 0,255 mmol), NaOAc (19 $\mathrm{mg}, 0,255 \mathrm{mmol}$ ) and compound 1 (110 mg, 0,255 mmol) was added methanol $\left(10 \mathrm{~cm}^{3}\right)$ and heated to $80^{\circ} \mathrm{C}$ for 18 hours. The resulting solution was evaporated, the solid obtained was dissolved in dichloromethane and filtered through silica, after which the solvent was removed under vacuum and a yellow bright powder was obtained. Yield $117 \mathrm{mg}$ (78,9\%). Anal. Calc. for $\mathrm{C}_{28} \mathrm{H}_{27} \mathrm{CINPPdS}: \mathrm{C}, 57.74 ; \mathrm{H}, 4.67 ; \mathrm{N}, 2.40$. Found: $\mathrm{C}, 57.70 ; \mathrm{H}, 4.71 ; \mathrm{N}, 2.36 .{ }^{1} \mathrm{H}$ NMR $(\mathrm{CDCl} 3): \sigma=2.28(\mathrm{~s}, 3 \mathrm{H}), 2.39(\mathrm{~s}, 6 \mathrm{H}), 2.74(\mathrm{~s}, 3 \mathrm{H}), 6.60(\mathrm{~d}, 1 \mathrm{H}), 6.69(\mathrm{~m}, 2 \mathrm{H}), 6.82(\mathrm{~m}, 2 \mathrm{H})$, $7.29(\mathrm{~m}, 5 \mathrm{H}), 7.70(\mathrm{~m}, 4 \mathrm{H}), 7.95(\mathrm{~m}, 1 \mathrm{H}),{ }^{31} \mathrm{P}\{1 \mathrm{H}\} \mathrm{NMR}(\mathrm{CDCl} 3): \sigma=45.37 \mathrm{~s}$.

\section{Synthesis of the compound 3}

To a mixture of triphenylphosphine $(22,5 \mathrm{mg}, 0,086 \mathrm{mmol})$, compound 2 (50 $\mathrm{mg}, 0,086$ $\mathrm{mmol}$ ) and ammonium hexafluorophosohate $(14 \mathrm{mg}, 0,086 \mathrm{mmol})$ were added acetone $\left(10 \mathrm{~cm}^{3}\right)$ and stirred for 18 . The resulting white solid $\left(\mathrm{NH}_{4} \mathrm{Cl}\right)$ was separated by centrifugation and the solution was evaporated to give a yellow powder. Yield $61 \mathrm{mg}$ (71\%). Anal. Calc. for $\mathrm{C}_{46} \mathrm{H}_{42} \mathrm{~F}_{6} \mathrm{NP}_{3} \mathrm{PdS}$ : $\mathrm{C}, 68.27 ; \mathrm{H}, 5.23 ; \mathrm{N}, 1.73$. Found: $\mathrm{C}, 68.28 ; \mathrm{H}, 5.27$; $\mathrm{N}, 1.71 .{ }^{1} \mathrm{H} \mathrm{NMR}(\mathrm{CDCl} 3): \sigma=1.65(\mathrm{~s}, 3 \mathrm{H}), 1.83(\mathrm{~s}, 3 \mathrm{H}), 2.45(\mathrm{~s}, 6 \mathrm{H}), 6.51(\mathrm{~m}, 1 \mathrm{H}), 6.68(\mathrm{~d}$, $1 \mathrm{H}), 6.78(\mathrm{~m}, 3 \mathrm{H}), 6.69(\mathrm{~m}, 1 \mathrm{H}), 7.18(\mathrm{t}, 1 \mathrm{H}), 7.40(\mathrm{~m}, 4 \mathrm{H}), 7.49(\mathrm{~m}, 6 \mathrm{H}), 7.56(\mathrm{~m}, 3 \mathrm{H})$, $7.67(\mathrm{~m}, 10 \mathrm{H}),{ }^{31} \mathrm{P}\{1 \mathrm{H}\} \mathrm{NMR}(\mathrm{CDCl} 3): \sigma=36.82(\mathrm{~s}), 42.51(\mathrm{~s})$

\section{Acknowledgments}

We wish to thank the financial support received from the Xunta de Galicia (Galicia, Spain) under the Grupos de Referencia Competitiva Programme Projects GRC2015/009. F. Lucio-Martínez and F. Reigosa thank the Spanish Ministry of Education (grant FPU13/05014 and FPU15/07145) 


\section{References}

[1] H Staudinger, J Meyer, Helv. Chim. Acta 2 (1): 635

[2] A.V. Kirsanov, Izv. Akad. Nauk. SSSR, Ser. Khim. (1950) 426-437

[3] F. Palacios, C. Alonso, D. Aparicio, G. Rubiales, J.M. de los Santos, Tetrahedron 63 (2006) 523-575;

[4] Pingrong Wei, Katie T. K. Chan and Douglas W. Stephan Dalton Trans. 2003, 38043810

[5] M. Fukui, K. Itoh, Y. Ishii, Bull. Chem. Soc. Jpn. 48 (1975) 2044- 2046

[6] N. Lease, V. Vasileviski, M. Carreira, A. de Almeida, M. Sanaú, P. Hirva, A. Casini and M. Contel, J. Med. Chem., 2013, 56, 5806

[7] N. Shaik, A. Martinez, I. Augustin, H. Giovinazzo, A. Varela, R. Aguilera, M. Sanaú, M. Contel, Inorg. Chem. 48 (2009) 1577-1587

[8] D. L. Ma, H. Z. He, K. H. Leung, D. S. H. Chan and C.H. Leung, Angew. Chem., Int. Ed., 2013, 52, 2.

[9] S. Ramírez-Rave, F. Estudiante-Negrete, R. A. Toscano, S. Hernández-Ortega, D. Morales-Morales, J.-M. Grévy, J. Organomet. Chem. 2014, 749, 287-295. 